\title{
Carcass and meat characteristics of Dorper x Santa Ines lambs finished in pasture, silvopastoral system, and feedlot
}

\section{Características da carcaça e da carne de cordeiros Dorper x Santa Inês terminados em pastagem, sistema silvipastoril e confinamento}

\begin{abstract}
Bruna Martins de Menezes ${ }^{1 *}$; Daniel Gonçalves da Silva2; Bento Martins de Menezes Bisneto3; Arthur Fernandes Bettencourt2; Giovane Menegon Pias"; Angélica Pereira dos Santos Pinho5; José Victor Vieira Isola6; Andressa Radtke Baungratz $^{7}$; Vicente de Paulo Macedo ${ }^{8}$
\end{abstract}

\section{Highlights}

Feedlot finished lambs have better carcass characteristics.

Shading did not affect the performance of lambs finished on pasture.

Lambs finished in pasture and feedlot had similar meat composition.

\section{Abstract}

The objective of this work was to evaluate the quantitative and qualitative characteristics of carcass and meat of Dorper $x$ Santa Ines crossbred lambs finished in a silvopastoral system, pasture or feedlot. Twentyfour non-castrated male lambs were used ( 8 animals in each production system). The experimental design was completely randomized, with three production systems and eight replications. The production systems were: pasture of Megathyrsus maximus cv. Aruana, without shading + feed supplementation (Pasture); pasture of Megathyrsus maximus cv. Aruana, with natural shading provided by the native laurel tree (Cordia

1 Master Student of Animal Science, Universidade Tecnológica Federal do Paraná, UTFPR, Dois Vizinhos, PR, Brazil. E-mail: bruh.menezes@hotmail.com

2 PhD Students of Animal Science, Universidade Federal do Rio Grande do Sul, UFRGS, Porto Alegre, RS, Brazil. E-mail: danielgonzootec@gmail.com; arthurfbettencourt@gmail.com

3 Master Student of Animal Science, Universidade Federal do Pampa, UNIPAMPA, Uruguaiana, RS, Brazil. E-mail: bewto@hotmail.com

4 Animal Scientist, UNIPAMPA, Dom Pedrito, RS, Brazil. E-mail: zootecpias@gmail.com

5 Profa Dra, Departament of Animal Science, UNIPAMPA, Dom Pedrito, RS, Brazil. E-mail: angelicapinho@unipampa. edu.br

6 PhD Student of Veterinary Science, Universidade Federal de Pelotas, UFPEL, Pelotas, RS, Brazil. E-mail: jv.isola@ hotmail.com

7 PhD Student of Animal Science, Universidade Estadual do Oeste do Paraná, UNIOESTE, Marechal Cândido Rondon, PR, Brazil. E-mail: zootecnistaandressa@gmail.com

8 Prof. Dr., Animal Science Research Program, UTFPR, Dois Vizinhos, PR, Brazil. E-mail: vicentepmacedo@utf.edu.br

* Author for correspondence

Received: May 05, 2021 - Approved: Sept. 02, 2021 
trichotoma) + feed supplementation (Silvopastoral) and feedlot. The cold carcass weight, empty body weight, cold carcass yield, fat color, fat consistency and carcass compactness index showed significant differences $(P<0.05)$ between production systems, with higher values observed in the feedlot. The shoulder weight and the percentage of shoulder components (bones, muscle, fat and others), did not significantly differ $(P>0.05)$ between production systems. The pasture silvopastoral systems presented similar results and also, when contrasted with the feedlot system, did not influence the parameters related to meat. Feedlot provided better quantitative and qualitative characteristics to the lambs' carcassess.

Key words: Aruana. Dorper. Carcass fat cover. Longissimus. Santa Ines.

\section{Resumo}

O objetivo deste trabalho foi avaliar as características quantitativas e qualitativas da carcaça e da carne de cordeiros mestiços Dorper $x$ Santa Inês terminados em sistema silvipastoril, a pasto e confinamento. Foram utilizados 24 cordeiros machos não castrados ( 8 animais em cada tratamento). 0 delineamento experimental foi inteiramente casualizado com três tratamentos e oito repetições. Os tratamentos foram: pastagem de Megathyrsus maximus cv. Aruana, sem sombreamento + suplementação alimentar (Pastagem); pastagem de Megathyrsus maximus cv. Aruana, com sombreamento natural proporcionado pela espécie arbórea Louro-Pardo Nativo (Cordia trichotoma) + suplementação alimentar (Sivilpastoril) e confinamento em aprisco. O peso de carcaça fria, peso de corpo vazio, rendimento de carcaça fria, cor da gordura, consistência da gordura e índice de compacidade da carcaça apresentaram diferença significativa entre os tratamentos $(P<0.05)$, com valores superiores observados no confinamento. $O$ peso das paletas e a porcentagem dos componentes da paleta (ossos, músculo, gordura e outros), não diferiram significativamente $(P>0.05)$ entre os sistemas de produção. Os sistemas a pasto sem sombreamento e silvipastoril apresentaram resultados similares, e quando contrastados ao confinamento não apresentaram influência nos parâmetros relacionados a carne. O confinamento proporcionou melhores características quantitativas e qualitativas às carcaças dos cordeiros.

Palavras-chave: Aruana. Cobertura de gordura da carcaça. Dorper. Longissimus. Santa Ines.

\section{Introduction}

The evolution of sheep production is a consequence of the application of genetic improvement and the use of technological systems. Among these systems we can mention the feedlot, the use of pasture combined with food supplementation and mainly, the silvopastoral system. However, there is a lack of comparative information between these production systems to better elucidate their potential for use.
In feedlot, the increase in lamb production is accentuated, as it allows the animal to be finished in a shorter period of time, with excellent conformation and fat coverage. However, this practice is increasingly costy, opening the way for other production systems (Barros et al., 2015; Oliveira, Ferreira, Freitas, Urbano, \& Silva 2017). Thus, pasture with supplementation is an interesting alternative, since it has low cost, is sustainable, an results in slaughtering young animals and of excellent nutritional quality for consumers (Santos, Azenha, Souza, Reis, \& Ruggieri, 2011; Lira et al., 2017). 
On the other hand, the silvopastoral system has stood out, being characterized by the integration of soil-plant-animal. This system contributes with numerous productive factors, such as intensification of the efficiency of natural resources, expansion of production per area and collaborating with animal production in a quantitative way and qualitative (Ferreira, Estrada, Thiébaut, Granados, \& Souza, 2011). It is worth noting that this system also enables better nitrogen fixation, nutrient recycling, soil moisture preservation, erosion reduction, better pasture maintenance, and also increases the system's profitability. In addition, shading contributes to animal welfare, promoting thermal comfort, minimizing stress and increasing animal productivity (Estremote, Melo, \& Pinheiro 2015; Porto, Martins, Pedrozo, Valério, \& Ciavarelli, 2016).

Allied to productive systems, genetic improvement adds in order to provide higher performance animals. The Santa Ines breed is widely used in Brazil, as it has good adaptability to adverse conditions, resistance to endoparasites, prolificity, good productive performance and demonstrates genetic potential in industrial crosses with greater aptitude for meat, such as the Dorper breed (Castro et al., 2016). Thus, the crossbred the Dorper x Santa Ines breeds brings together attributes that provide better slaughter performance and excellent yields and carcass characteristics, such as fat coverage (Amaral et al., 2011; Cartaxo et al., 2017).

However, only few studies have compared silvopastoral systems and the benefits that these systems can add to sheep farming, to other systems such as pasture with supplementation and feedlot. Therefore, the aim of this study was to evaluate whether the feedlot, supplemented pasture and silvopastoral systems affect the qualitative and quantitative characteristics of carcass and meat of lambs from the crossbred Dorper x Santa Ines.

The first hypothesis of this study is that lambs finished in feedlot present better performance and carcass and meat characteristics than those finished in pasture. The second is that animals finished in a silvopastoral system present better performance than those finished in pasture without access to shading.

\section{Material and Methods}

The study was conducted at the Technological Federal University of Paraná (UTFPR), Campus Dois Vizinhos, Brazil. The institution is located in a physiographic region called the third plateau of Paraná, having an altitude of $520 \mathrm{~m}$, latitude of $25^{\circ} 44^{\prime \prime}$ South and longitude of $53^{\circ} 04^{\prime \prime}$ West. The climate is humid subtropical mesothermal (Cfa and $\mathrm{Cfb})$, according to the Köppen classification (Instituto Agronômico do Paraná [IAPAR], 2011). The soil is red distroferric latosol and the terrain has around 5\% slope. The average values for air temperature $\left({ }^{\circ} \mathrm{C}\right)$ and relative humidity (\%) were $22.74^{\circ} \mathrm{C}$ and $76.19 \%$, respectively. The climatic data were collected at the weather station of the UTFPR - Dois Vizinhos, located approximately 200 meters from the experimental area.

All procedures used in the experiment were previously approved by the Animal Use Ethics Committee (CEUA) at the Technologycal Federal University of Paraná (UTFPR), under the protocol number 2016/028. The experiment was conducted from December 2016 to March 2017. 


\section{Animals, diets, and experimental design}

The production systems evaluated were: Pasture $=$ lambs finished on tropical pasture (Megathyrsus maximus cv. Aruana) without shade + daily feed supplementation at $1.5 \%$ of body weight (BW) on a dry matter (DM) basis; Silvopastoral = lambs finished on tropical pasture (Megathyrsus maximus cv. Aruana) with shading + feed supplementation

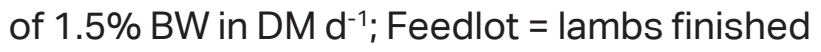
in feedlot, receiving a diet with $200 \mathrm{~g} \mathrm{~kg}^{-1}$ of roughage (ryegrass hay) and $800 \mathrm{~g} \mathrm{~kg}^{-1}$ of concentrate (20:80), on a DM basis.

The area of the pasture system corresponded to $1600 \mathrm{~m}^{2}$ (0.16 ha), subdivided into four $400 \mathrm{~m}^{2}$ (0.04 ha) paddocks, equipped with feeding and drinking troughs. The silvopastoral system was implemented in September 2013, in the east-west direction, with the trees arranged in double rows (two rows of trees), with the distance between trees of two meters in the same row and one meter between one row and another in each $400 \mathrm{~m}^{2}$ paddock. The distance between a row of trees from one paddock to another was approximately ten meters. For pasture management, it was used the grazing method with continuous stocking and variable stocking rate to correspond to the put-andtake technique (Mott \& Lucas, 1952). Pasture evaluations were performed at intervals of 21 days, aiming to maintain a constant supply of 10\% (10 kg DM per $100 \mathrm{~kg} \mathrm{BW} \mathrm{per} \mathrm{day).} \mathrm{Forage}$ grazing and forage mass estimation ([FM], $\mathrm{kg} \mathrm{ha}^{-1} \mathrm{DM}$ ) were performed using a double sampling method (Wilm, Costello \& Klipple, 1944). Pasture grass height was measured using a graded ruler at random points in the pens. Average FM in pasture and silvopastoral systems was $2440.87 \mathrm{~kg} \mathrm{ha}^{-1}$ DM (average grass height $12.43 \mathrm{~cm}$ ) and $2048.89 \mathrm{~kg} \mathrm{ha}^{-1} \mathrm{DM}$ (average grass height $13.48 \mathrm{~cm}$ ), respectively.

The lambs in feedlot remained throughout the experimental period in a pen with a total area of approximately $72 \mathrm{~m}^{2}(0.0072$ ha), subdivided into 11 stalls of $4 \mathrm{~m}^{2}$ each, a $4 \mathrm{~m}^{2}$ utensil room, and a $24 \mathrm{~m}^{2}$ central corridor. The stalls were equipped with feeders, automatic drinking troughs and individual feeding troughs. In the feedlot system, the sheep underwent a 14-day adaptation period. The feed supplied was regulated according to the daily consumption of the animals, in quantities adjusted to provide $10 \%$ of feed leftovers in the troughs. The lambs were fed twice a day, with $50 \%$ of the feed being provided at 8:00 am and the rest at 3:00 pm. The diets were prepared according to the nutritional requirements of lambs in the finishing phase, containing $180 \mathrm{~g} \mathrm{~kg}^{-1}$ crude protein (CP) and $730 \mathrm{~g} \mathrm{~kg}^{-1}$ of total digestible nutrients (TDN), on a DM basis (National Research Council [NRC], 2007). The commercial mineral supplement was supplied directly in the troughs in the enclosures at a rate of approximately $20 \mathrm{~g}$ animal ${ }^{-1} \mathrm{~d}^{-1}$. The chemical composition of the diet and ingredient proportions are shown in Tables 1 and 2, respectively. 
Table 1

Chemical composition of feed and experimental diets of crosbreed Dorper $x$ Santa Ines lambs in the pasture, silvopastoral, and feedlot systems

\begin{tabular}{|c|c|c|c|c|c|c|}
\hline \multirow{2}{*}{$\begin{array}{l}\text { Compositionl } \\
\left(\mathrm{g} \mathrm{kg}^{-1}\right)\end{array}$} & \multicolumn{6}{|c|}{ Experimental feed } \\
\hline & \multicolumn{2}{|r|}{ Corn meal } & \multicolumn{2}{|c|}{ Soybean meal } & \multicolumn{2}{|c|}{ Wheat bran } \\
\hline $\mathrm{DM}^{*}$ & \multicolumn{2}{|r|}{898.3} & \multicolumn{2}{|c|}{873.7} & \multicolumn{2}{|c|}{883.8} \\
\hline $\mathrm{CP}$ & \multicolumn{2}{|r|}{97.5} & \multicolumn{2}{|c|}{487.7} & \multicolumn{2}{|c|}{145.6} \\
\hline NDF & \multicolumn{2}{|r|}{162.0} & \multicolumn{2}{|c|}{165.2} & \multicolumn{2}{|c|}{453.7} \\
\hline ADF & \multicolumn{2}{|r|}{38.9} & \multicolumn{2}{|c|}{104.1} & \multicolumn{2}{|c|}{154.3} \\
\hline $\mathrm{TDN}^{* *}$ & \multicolumn{2}{|r|}{878.0} & \multicolumn{2}{|c|}{790.7} & \multicolumn{2}{|c|}{$770.4^{*}$} \\
\hline \multicolumn{7}{|c|}{ Lamb production system $§$} \\
\hline & \multicolumn{3}{|c|}{ Concentrate } & \multicolumn{3}{|c|}{ Bulk $\S^{\S}$} \\
\hline & Pasture & Silvopastoral & Feedlot & Pasture & Silvopastoral & Feedlot \\
\hline $\mathrm{DM}^{*}$ & 881.3 & 881.3 & 884.4 & 27.1 & 25.5 & 898.4 \\
\hline $\mathrm{CP}$ & 190.5 & 190.5 & 214.8 & 139.0 & 151.0 & 62.0 \\
\hline NDF & 121.6 & 121.6 & 145.0 & 578.9 & 551.1 & 684.4 \\
\hline ADF & 64.8 & 64.8 & 65.3 & 430.2 & 432.1 & 439.8 \\
\hline $\mathrm{TDN}^{* *}$ & 837.7 & 837.7 & 839.8 & 577.3 & 575.9 & 545.9 \\
\hline
\end{tabular}

'DM: dry matter; CP: crude protein; NDF: neutral detergent fiber; ADF: acid detergent fiber; TDN: total digestible nutrients. $\S$ Chemical composition of the concentrate and bulk fractions per treatment. §§Chemical composition of simulation of continuos grazing (pasture e silvopastoral) and ryegrass hay (feedlot). * $\mathrm{g} / \mathrm{kg}$ of natural matter; **TDN estimate according to Rodrigues (2009): TDN: 87.84 - (0.70 x ADF).

\section{Table 2}

Concentrate sources supplied to crossbreed Dorper x Santa Ines lambs in the pasture, silvopastoral, and feedlot systems

\begin{tabular}{|c|c|c|c|}
\hline \multirow{2}{*}{ Feed $\left(\mathrm{g} \mathrm{kg}^{-1}\right)$} & \multicolumn{3}{|c|}{ Lambs production systems } \\
\hline & Pasture & Silvopastoral & Feedlot' \\
\hline Corn meal & 661.5 & 661.5 & 634.9 \\
\hline Wheat bran & 98.5 & 98.5 & 64.5 \\
\hline Soybean meal & 228.9 & 228.9 & 294.2 \\
\hline Calcitic limestone & 11.1 & 11.1 & 6.4 \\
\hline Total & 1000.0 & 1000.0 & 1000.0 \\
\hline
\end{tabular}

'Diet composed of $800 \mathrm{~g} \mathrm{~kg}^{-1}$ of concentrate and $200 \mathrm{~g} \mathrm{~kg}^{-1}$ of ryegrass hay.

Twenty-four non-castrated male Dorper x Santa Ines crossbred lambs $(n=24)$ with a mean age of 138 days and $22.97 \mathrm{~kg}$ of
BW were used in the experiment (Table 3). The lambs were weighed on day zero and then every 21 days. On the same oportunity, the 
subjective evaluation of the body condition status (BCS) was performed. The BCS, scored between 1 (very thin) and 5 (very fat), according to Russel, Doney and Gunn (1969). The data of performance and BCS of lambs in the three production systems are presented in Table 3.

\section{Table 3}

\section{Performance of crossbred Dorper x Santa Ines lambs finished in the pasture, silvopastoral, and feedlot} systems

\begin{tabular}{|c|c|c|c|}
\hline \multirow{2}{*}{ Variable! } & \multicolumn{3}{|c|}{ Lambs production systems } \\
\hline & Pasture & Silvopastoral & Feedlot \\
\hline Initial BW (kg) & $23.54 \pm 1.77$ & $23.12 \pm 2.58$ & $22.24 \pm 2.13$ \\
\hline Initial age (days) & $139 \pm 4$ & $136 \pm 8$ & $140 \pm 8$ \\
\hline Initial BCS (1-5 points) & $2.43 \pm 0.19$ & $2.50 \pm 0.41$ & $2.14 \pm 0.38$ \\
\hline Slaughter BCS (1-5 points) & $3.14 \pm 0.55$ & $2.93 \pm 0.34$ & $4.07 \pm 0.34$ \\
\hline ADG (kg day $\left.{ }^{-1}\right)$ & $0.169 \pm 0.050$ & $0.147 \pm 0.030$ & $0.238 \pm 0.050$ \\
\hline
\end{tabular}

'BW = live weight; BCS = body condition score (1 - very lean animal; 5 - very fat animal); $A D G=$ average daily gain. Values expressed as mean and standard error.

\section{Slaughter procedure, carcass evaluation and meat sampling}

When the lambs reached the preestablished live weight of slaughter (SLW) of $40 \mathrm{~kg}$ they were submitted to a $16 \mathrm{~h}$ fasting and were subsequently weighed to obtain body weight at slaughter (SW). The animals were stunned by the electrical method (electronarcosis), followed by bleeding with a cut in the carotid artery and jugular veins and, later, evisceration according to the normative instruction $\mathrm{N}^{\circ} 3$ of January 17, 2000 of the Ministry of Agriculture, Livestock and Food Supply - Secretariat of Agricultural Defense.

After evisceration, the empty body weight (EBW) (A. G. Silva, 2001) and the hot carcass weight $(\mathrm{HCW})$ were obtained. The carcasses were then transferred to a refrigerated chamber at $4^{\circ} \mathrm{C}$, where they remained for 24 hours, hanging by the tendons on appropriate hooks to maintain a distance of
$17 \mathrm{~cm}$ between the tarsometatarsal joints (A. G. Silva, Purchas, Kadim, \& Yamanoto, 2005). At the end of the 24 hours, the carcasses were weighed again to obtain the cold carcass weight (CCW, $\mathrm{kg}$ ), which was used to determine the cold carcass yield (CCY, \%). The $\mathrm{CCY}$ is obtained by the formula: $\mathrm{CCY}=(\mathrm{CCW} /$ SLW) $\times 100$. The percentage of chilling weight loss (CWL, \%) was also calculated, using the formula: $\mathrm{CWL}=((\mathrm{HCW}-\mathrm{CCW}) / \mathrm{HCW}) \times 100$. This loss consists of moisture loss from the carcass after cooling, due to the cooling process and chemical reactions in the muscle (Kirton, 1986).

Next, with the aid of a measuring tape, the following measurements were taken from the carcasses: leg length (LL) (m), which corresponds to the distance between the perineum, and the anterior edge of the tarsometatarsal articular surface. Internal carcass length (ICL) (m), which is the distance 
between the anterior edge of the ischi-pubic symphysis, and the anterior edge of the first rib at its midpoint, and the rump width (RW) $(\mathrm{m})$, which is the maximum width between the trochanters of both femurs (Sañudo \& Sierra, 1986), taken with a compass.

Carcass compactness index (CCl) $(\mathrm{kg}$ $\mathrm{cm}^{-2}$ ) was calculated by the ratio of the cold carcass weight in relation to the internal length of the carcass. The leg compactness index (LCI) $\left(\mathrm{cm}^{2}\right)$, by the croup width in relation to leg length. These indices are indicators of the muscular constitution of the carcass (Sañudo \& Sierra, 1986).

Carcasses were subjectively evaluated according Osório and Osório (2005) for the degree of carcass conformation (CC), which refers to the ratio of muscle to bone, with a scale of 1.00 (very poor) to 5.00 (excellent musculature). Considering the carcass as a whole, and emphasizing the anatomical regions, leg, croup, loin and scapula and the thickness of their muscle, and fat planes in relation to the skeleton that supports it. The carcass was divided in half by the longitudinal cut to obtain the half carcasses. On the left half carcass, the meat cuts were measured, with emphasis on the loin cut, obtained by sectioning the 12th to 13th lumbar vertebra (Osório, 1998).

The cuts were classified in regard to fat cover, using a scale of 1 for lean and 5 for very fat (A. G. Silva \& Osório 2008). The fat color was also graded, being 1.00 for white and 3.00 for yellow. Fat consistency was graded from 1.00 being firm and 3.00 soft, and meat color was graded from pink (1.00) to purple (3.00) (Cézar \& Sousa, 2007). All subjective analyzes were performed by a single evaluator with experience in the field.
In the loin meat cut (Longissimus thoracis et lumborum) between the last thoracic vertebra and the first lumbar vertebra, measurements were taken with the aid of a digital caliper to calculate the loin eye area (LEA) and subcutaneous fat thickness (SFT) according to A. G. Silva et al. (2005). The loin eye area (LEA) was obtained using the geometric method from the following equation: $\operatorname{LEA}=(A / 2 \times B / 2) \times \pi$, where: LEA: loin eye area $\left(\mathrm{cm}^{2}\right)$; $A$ : major muscle length; $B$ : minor muscle length; $\pi=3.1416$.

Nine loins (3 per production system) (Longissimus thoracis et lumborum) were separated, as well as 15 shoulders (5 per production system). Between the 12th and 13th ribs, transversal cuts were made in order to remove a portion called "HH section", according to the methodology proposed by Cañeque and Sañudo (2005) and later adapted by Muller (1987) aiming to expose the Longissimus thoracis et lumborum muscle.

Next, two slices with thickness of 2.5 $\mathrm{cm}$ each were removed from the samples. The slices were weighed while still frozen (average weight of $0.129 \mathrm{~kg}$ ) and after thawing (average weight of $0.124 \mathrm{~kg}$ ). These weighings helped to determine the moisture loss during the thawing process, which was carried out in a refrigerator for 24 hours.

The shoulders were individually weighed and dissected with the aid of a scalpel. The amount of fat, muscle, bone and others was weighed to determine the proportion (\%) of each component according to ColomerRocher, Morand-Fehr and Kirton (1987). In this case, "other" refers to the presence of lymph nodes, large blood vessels, prominent nerves, ligaments, and tendons. 


\section{Meat quality evaluation}

To determine the thawing loss (TL), the slices loin was thawed under refrigeration until they reached an internal temperature of 2 to $5^{\circ} \mathrm{C}$. The $\mathrm{TL}$ was calculated by the difference between the weight of the samples before and after thawing, being expressed in percentage. To determine cooking loss (CKL) and shear force (SF), 9 loin samples (3 per feed management system) were boiled in a water bath inside a heat-resistant plastic container until they reached an internal temperature of $70{ }^{\circ} \mathrm{C}$ and, subsequently, were cooled. The CKL corresponded to the difference in weight between the samples before and after cooking, expressed as a percentage (Hamm, 1961). For the evaluation of the SF, six portions were taken in a cylindrical shape with $1.27 \mathrm{~cm}$ in diameter from each sample, that was used to determine the CKL. These portions were cut perpendicularly to the direction of the muscle fibers in a texturometer coupled to the Warner-Bratzler TA-XT Plus model, which

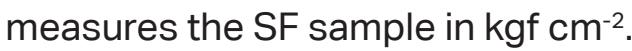

\section{Statistical analysis}

The experimental design used was completely randomized, with three production systems and eight replications. Data were submitted to the Shapiro-Wilk test to verify the normality of the data. The data referring to BCS, CC and color of meat and fat did not present normal distribution, being submitted to the Kruskal-Wallis test (PROC NPAR1WAY Wilcoxon). Data that presented normal distribution were submitted to analysis of variance by the PROC GLM procedure. The analyses were performed using the SAS 9.1 (2001) statistical package, using the Tukey test to compare means at a significance level of $5 \%$.

\section{Results and Discussion}

There were no significant differences $(P>0.05)$ for age at slaughter, length of time the animals remained in the finishing phase, and CWL (Table 4).

\section{Table 4}

Performance and carcass characteristics of crossbred Dorper $x$ Santa Ines lambs finished in the pasture, silvopastoral, and feedlot systems

\begin{tabular}{|ccccc}
\hline Variable & \multicolumn{3}{c}{ Lambs production systems } \\
Age at slaughter (days) & $224 \pm 26$ & $235 \pm 23$ & $215 \pm 24$ & 0.3465 \\
Finishing time (days) & $85 \pm 26$ & $99 \pm 23$ & $75 \pm 20$ & 0.1841 \\
SLW (kg) & $36.93 \pm 1.27 \mathrm{~b}$ & $37.26 \pm 1.87 \mathrm{ab}$ & $39.21 \pm 1.57 \mathrm{a}$ & 0.0313 \\
EBW (kg) & $33.86 \pm 1.28 \mathrm{~b}$ & $34.21 \pm 1.95 \mathrm{~b}$ & $37.08 \pm 2.14 \mathrm{a}$ & 0.0073 \\
HCW (kg) & $17.26 \pm 0.62 \mathrm{~b}$ & $17.27 \pm 0.85 \mathrm{~b}$ & $19.08 \pm 1.53 \mathrm{a}$ & 0.0120 \\
CCW (kg) & $16.62 \pm 0.65 \mathrm{~b}$ & $16.57 \pm 0.89 \mathrm{~b}$ & $18.39 \pm 1.60 \mathrm{a}$ & 0.0102 \\
CCY (\%) & $45.02 \pm 1.17 \mathrm{~b}$ & $44.46 \pm 0.85 \mathrm{~b}$ & $46.82 \pm 2.30 \mathrm{a}$ & 0.0293 \\
CWL (\%) & $3.70 \pm 0.44$ & $4.09 \pm 1.44$ & $3.63 \pm 0.45$ & 0.6059
\end{tabular}

ISLW = slaughter live weight; EBW = empty body weight; $\mathrm{HCW}=$ hot carcass weight; $\mathrm{CCW}=$ cold carcass weight; $\mathrm{CCY}=$ cold carcass yield; $\mathrm{CWL}=$ chilling weight loss. Values expressed as mean and standard error.

Means in the same row, followed by different letters, differ by the Tukey test, at $5 \%$ significance level. 
The SLW differed $(\mathrm{P}<0.05)$ between production systems, with higher weights for feedlot, lower weights for pasture, and intermediate weights for silvopastoral system. This result is likely due to the better ADG of feedlot lambs compared to pasture systems (Table 3). In feedlot systems, it is common for weight gain to be enhanced, resulting in the slaughter of animals at younger ages and with standardized carcasses in terms of weight, conformation and fat coverage (Leite et al., 2020). In the present study, there was no significant difference for the finishing time, but the feedlot lambs still performed better.

The CCW varied significantly $(\mathrm{P}<0.05)$ between the production systems, with superiority in the feedlot system, when compared to the pasture and silvopastoral systems (Table 4). However, the CCW obtained in the present study was higher than the average weight of $12.63 \mathrm{~kg}$ reported by Garcia, Cidrão, Spers, Colombo and Trevizan (2016), when evaluating lambs on pasture with supplementation, and the weight of $15.59 \mathrm{~kg}$ presented by M. C. Lima et al. (2012), when analyzing the performance of feedlot lambs. This variation is possibly related to the BW (Atti \& Mahouachi, 2011), SLW and EBW between the different experiments, and is enhanced due to production systems, nutritional level, age and BCS.

The EBW was higher $(\mathrm{P}<0.05)$ among the feedlot lambs compared to animals in the pasture systems. This difference was possibly due to the nature of the predominant feed provided in the pasture systems (bulk) compared to feedlot(concentrate), considering that the live weight, which precedes the fasting period, was the same between treatments (Queiroz et al., 2015).
The CCY of lambs varied $(P<0.05)$ between production systems (Table 4), with superiority for animals in the feedlot compared to the pasture systems. According to Cruz, Santos, Azevedo and Silva (2016), carcass yields can vary from 45 to $60 \%$, and these values are influenced by intrinsic factors such as age and slaughter weight, and also by extrinsic factors such as nutritional level, pasture type, and management. Carcass characteristics can also influence CCY, being the most common: BW, carcass length, LEA and carcass conformation. Pilecco et al. (2018) when evaluating the carcass characteristics and noncarcass components of lle de France lambs finished in feedlot with different levels of cottonseed inclusion in the diet, obtained average CCY (46.02\%) similar to those observed in the present study for the pasture and feedlot systems.

The CWL averaged $3.80 \%$ between production systems (Table 4) and is in accordance with acceptable levels for lambs, which, according to L. D. Lima et al. (2013), can range from 3 to $4 \%$. For Carvalho et al. (2012), lower percentages of CWL correspond to satisfactory productive managements in the field, promoting a better degree of finishing on the uniformity of fat deposition in sheep.

The $\mathrm{LL}, \mathrm{RW}$ and $\mathrm{LCl}$, did not differ $(P>0.05)$ between lambs finished on pasture, silvopastoral, and feedlot systems (Table 5). D. D. Alves et al. (2013), evaluating the carcass characteristics of Santa Ines crossbred lambs in different finishing systems, found an average for LL of $0.37 \mathrm{~m}$, lower than that obtained in the different production systems in the present study. The RW presented an average of 0.25 m. Jucá et al. (2016) and N. V. Silva et al. (2016), found approximate values for RW in Santa 
Ines lambs on pasture $(0.21 \mathrm{~m})$ and in feedlot $(0.22 \mathrm{~m})$, respectively. The average $\mathrm{LCl}$ for the evaluated production systems was $0.50 \mathrm{~kg}$ $\mathrm{cm}^{-1}$. Queiroz et al. (2015) when analyzing the quantitative characteristics of the carcasses of Santa Ines lambs under feedlot, observed a higher average for the $\mathrm{LCl}\left(0.59 \mathrm{~kg} \mathrm{~cm}^{-1}\right)$.

However, ICL differed $(P<0.05)$ between the production systems evaluated. Similar values were found between pasture and silvopastoral systems, as well as between pasture and feedlot systems (Table 5). Body length contains high correlation with carcass weight (D. L. S. Silva et al., 2015), besides being an excellent indicator of carcass quality and characteristics. The higher ICL observed between silvopastoral and pasture systems may be related to the age at slaughter of the lambs, as they remained a longer period of time in the finishing phase until they reached the predetermined SLW (40 kg BW). Thus, lambs in the silvopastoral and pasture systems remained 98 and 85 days in the finishing phase, respectively. The latter (85 days in pasture system) was close to that observed in feedlot (75 days), and hence, statistically similar.

\section{Table 5}

Carcass conformation of crossbred Dorper x Santa Ines lambs finished in the pasture, silvopastoral, and feedlot systems

\begin{tabular}{ccccc} 
Variable & \multicolumn{3}{c}{ Lambs production systems } \\
& Pasture & Silvopastoral & Feedlot & P-value \\
LL (m) & $0.51 \pm 0.02$ & $0.51 \pm 0.02$ & $0.50 \pm 0.02$ & 0.3822 \\
RW (m) & $0.25 \pm 0.01$ & $0.26 \pm 0.01$ & $0.25 \pm 0.02$ & 0.4372 \\
ICL (m) & $0.74 \pm 0.01 \mathrm{ab}$ & $0.75 \pm 0.02 \mathrm{a}$ & $0.73 \pm 0.02 \mathrm{~b}$ & 0.0528 \\
$\mathrm{CCl}\left(\mathrm{kg} \mathrm{cm}^{-1}\right)$ & $0.22 \pm 0.01 \mathrm{~b}$ & $0.22 \pm 0.01 \mathrm{~b}$ & $0.25 \pm 0.02 \mathrm{a}$ & 0.0074 \\
$\mathrm{LCl}\left(\mathrm{kg} \mathrm{cm}^{-1}\right)$ & $0.48 \pm 0.03$ & $0.50 \pm 0.03$ & $0.51 \pm 0.05$ & 0.5057 \\
$\mathrm{LEA}\left(\mathrm{cm}^{2}\right)$ & $11.02 \pm 0.94 \mathrm{~b}$ & $12.77 \pm 1.20 \mathrm{ab}$ & $13.67 \pm 2.63 \mathrm{a}$ & 0.0325
\end{tabular}

'LL = leg length; RW = rump width; ICL = internal carcass length; $\mathrm{CCI}$ = carcass compactness index; LCI = leg compactness index; LEA = loin eye area. Values expressed as mean and standard error.

Means in the same row, followed by different letters, differ by the Tukey test, at $5 \%$ significance level.

The $\mathrm{CCl}$ of the lambs showed significant difference $(\mathrm{P}<0.05)$ between production systems (Table 5). Animals in feedlot manifested higher value probably due to the higher CCW (Table 3), as it is a key information for $\mathrm{CCl}$ calculation (Pilecco et al., 2018). Queiroz et al. (2015), when evaluating the quantitative carcass characteristics of Santa Ines lambs in feedlot, found identical average $\mathrm{CCl}\left(0.25 \mathrm{~kg} \mathrm{~cm}^{-1}\right)$ than the ones observed in this study. An approximate value of $\mathrm{CCl}\left(0.24 \mathrm{~kg} \mathrm{~cm}^{-1}\right)$ was reported by Jucá et al. (2016), when evaluating Santa Ines lambs on pasture.

The LEA differed $(\mathrm{P}<0.05)$ among production systems and was higher in feedlot, lower in pasture and intermediate in silvopastoral system (Table 5). E. M. Alves et al. (2014), when evaluating crossbred Santa Ines 
lambs in feedlot system, observed that the LEA was between 12.00 to $14.00 \mathrm{~cm}^{2}$, similar to that obtained by Faria et al. (2011) and Oliveira et al. (2017). According to Hashimoto et al. (2012), there is generally a positive correlation between LEA with SLW. The LEA is an indication of the composition, quality and distribution of muscle in the carcass. Thus, the higher the LEA, the better the carcass meatiness (L. D. Lima et al., 2013; McManus et al., 2013). The carcass has different types of valuation. For the slaughterhouse the carcass yield is valued more than its components. The butchervalues conformation, age, finishing and tissue composition more. The producer values profitability and the consumer its appearance, amount of fat and tissue composition (L. G. C. Alves et al., 2015). To discover the tissue portion, the dissection of the carcass should be performed, a process that involves the separation of bone, muscle and fat, however, this methodology is justified only for specific purposes, because it is expensive, laborious and slow (L. G. C. Alves et al., 2015).

Shoulder weight did not differ $(P>0.05)$ between production systems (Table 6), with average weight of $1.585 \mathrm{~kg}$. Lower shoulder weight $(1.360 \mathrm{~kg})$ was verified by Lira et al. (2017), when slaughtering lambs of different biotypes of the Santa Ines breed at $32.5 \mathrm{~kg}$ of BW. Landim et al. (2017), when evaluating the carcass characteristics of Santalnes $x$ Broadtail and pured Broadtail lambs slaughtered at 28.6 $\mathrm{kg}$ and $24.1 \mathrm{~kg}$ of BW, showed shoulder weights lower than in this study $1.080 \mathrm{~kg}$ and $0.822 \mathrm{~kg}$, respectively. Thus, the variation in the weight of the shoulder for lambs slaughtered with different BW, demonstrating the influence of SLW on the development of this cut. And also, may present different proportions between bone development, muscle growth and fat deposition.

\section{Table 6}

Weight, yield, and tissue components (bones, muscle, fat and others) of crossbred Dorper x Santa Ines lambs finished in the pasture, silvopastoral, and feedlot systems

\begin{tabular}{ccccc} 
Variable & \multicolumn{2}{c}{ Lambs production systems } & \multicolumn{2}{c}{ P-value } \\
& Pasture & Silvopastoral & Feedlot & 0.1670 \\
Shoulder (kg) & $1539.3 \pm 51.3$ & $1554.2 \pm 82.6$ & $1664.0 \pm 131.3$ & 0.2324 \\
Bone (\%) & $21.65 \pm 1.25$ & $21.35 \pm 0.44$ & $18.59 \pm 0.84$ & 0.2444 \\
Muscle (\%) & $51.25 \pm 1.29$ & $53.25 \pm 2.77$ & $53.03 \pm 2.84$ & 0.2302 \\
Fat (\%) & $8.77 \pm 0.94$ & $6.59 \pm 3.36$ & $8.98 \pm 2.18$ & 0.0831 \\
Other (\%) & $18.33 \pm 2.01$ & $18.86 \pm 1.36$ & $19.41 \pm 1.84$ &
\end{tabular}

Values expressed as mean and standard error.

Means in the same row, followed by different letters, differ by the Tukey test, at $5 \%$ significance level.

The tissue composition of the shoulder in relation to the proportions (\%) of bone, muscle, fat and others did not differ $(P>0.05)$ between production systems (Table 6).
Guerrero, Valero, Campo and Sañudo (2013) reported that age, breed, sexual condition, slaughter weight, management, in addition to the production system, are a strong indication 
of possible changes between the proportions of muscle, fat and bone. A larger proportion of muscle is important in valuing the carcass or cut, adding commercial value to them. Higher value was reported by Pellegrini et al. (2018), for the proportion of muscle (57.95\%) and fat (14.58\%) of Texel x lle de France crossbred lambs. Also, the authors found lower proportions of bone and other, with values of 17.57 and $6.11 \%$, respectively.

The CC and meat color did not differ $(P>0.05)$ between production systems (Table 7). The meat color from pasture lambs and feedlot lambs showed a pinkish coloration (pigmentation), identified between 1 and 2 on the scale according to the methodology. The pigmentation is determined by the muscle protein called myoglobin that is present in the meat (Azeredo, Brito, \& Garruti, 2012). However, coloration can be influenced by factors such as the concentration of this protein, type of muscle fiber, pre- and post-slaughter management, pH (Gois et al., 2017), or also, by nutrition, climate, sex, physical activity, and age (Bertol, 2019). Thus, as the age of the animal advances, the amount of pigmentation that characterizes the color of the meat increases (Bertol et al., 2015), characterizing a coloration closer to purple (3).

\section{Table 7}

Carcass conformation and meat and fat traits of crossbred Dorper $\mathrm{x}$ Santa Ines lambs finished in the pasture, silvopastoral, and feedlot systems

\begin{tabular}{|c|c|c|c|c|}
\hline \multirow{2}{*}{ Variable! } & \multicolumn{3}{|c|}{ Lambs production systems } & \multirow{2}{*}{$P$-value } \\
\hline & Pasture & Silvopastoral & Feedlot & \\
\hline CC (1-5 points) & $2.36 \pm 0.40$ & $2.43 \pm 0.47$ & $2.86 \pm 0.75$ & 0.2250 \\
\hline Meat color (1-3 points) & $1.57 \pm 0.24$ & $1.50 \pm 0.29$ & $1.78 \pm 0.36$ & 0.2115 \\
\hline Fat cover (1-5 points) & $2.18 \pm 0.45 a b$ & $1.89 \pm 0.32 b$ & $2.71 \pm 0.51 a$ & 0.0075 \\
\hline Fat color (1-3 points) & $1.61 \pm 0.32 b$ & $1.50 \pm 0.25 b$ & $2.14 \pm 0.35 a$ & 0.0023 \\
\hline Fat consistency (1-3 points) & $1.46 \pm 0.22 b$ & $1.43 \pm 0.12 b$ & $1.93 \pm 0.40 a$ & 0.0050 \\
\hline
\end{tabular}

'CC = 1- very poorly muscled animal to 5-excellent in muscling; Meat color = 1- for pink and 3 for purple; Fat cover = 1- lean and 5- very fat; Fat color = 1- for white and 3- for yellow; Fat consistency = 1- for firm and 3- for soft. Values expressed as mean and standard error;

Means in the same row, followed by different letters, differed by the Tukey test, at $5 \%$ significance level.

Fat cover in the carcass of the lambs differed $(\mathrm{P}<0.05)$ between production systems (Table 7). This variable is directly related by the diet fed to the animals, influencing the quantity and quality of subcutaneous fat (Bertol, 2019). In feedlot, the higher fat cover was probably influenced by the higher proportion of concentrate in the diet and in pasture due to the high ADG compared to silvopastoral system (Table 3). Amaral et al. (2011), when evaluating the productive performance of Dorper x Santa Ines crossbred lambs in feedlot, showed similar value for fat cover. On the other hand, Cartaxo et al. (2017), when verifying the carcass characteristics of Santa Ines $x$ Dorper crossbred lambs in feedlot, obtained 
an average value of fat cover (3.35) higher than the production systems of the present study. Fat deposition in carcasses should be uniform, because it protects the muscle during cooling, preventing drying out and ensuring the flavor and juiciness of the meat. Carcasses with a layer of fat between 2 and $5 \mathrm{~mm}$ are the most accepted in the consumer market (Moreno \& Boaventura, 2016).

Fat color varied $(\mathrm{P}<0.05)$ between lambs finished in the different production systems (Table 7). Feedlot lambs showed a greater tendency to yellow on a scale of 1 to 3 (2.14), diverging from expected, since fat color is directly related to the presence of dietary carotenoids, which in turn is lower in grain and hay, when purchased for pasture (Leão et al., 2012). However, lambs finished in the pasture systems were classified with intermediate values for fat color, according to the methodology, not differing between pasture and silvopastoral systems.

The fat consistency of the feedlot lambs showed a leaned toward tender on a scale of 1 to 3 (1.93), expressing a significant difference $(\mathrm{P}<0.05)$ between the pasture and feedlot production systems (Table 7). Intrinsic and extrinsic factors can cause these changes, such as the feed provided to the animals, which can influence the different proportions of fatty acids, with more or less saturated fatty acid deposition (Bertol, 2019). Amaral et al. (2011), when evaluating the performance of mixed lambs between the Dorper $x$ Santa Ines breeds in feedlot, obtained a lower average for fat consistency (1.83), when contrasted with the animals in feedlot in the present study. However, the value is higher for animals finished in the pasture and silvopastoral systems.
The SF showed no significant difference $(P>0.05)$ between production systems, with values of $3.26 \pm 0.86 \mathrm{kgf}$

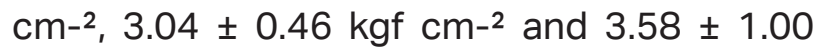
$\mathrm{kgf} \mathrm{cm}^{2}$, in pasture, silvopastoral and feedlot, respectively. The average for this parameter was $3.29 \mathrm{kgf} \mathrm{cm}^{-2}$, conferring very tender meat in all three production systems. Vargas et al. (2019), found similar mean value for SF (3.40 kgf $\mathrm{cm}-2)$ when evaluating the sensory profile of lambs from different crossbreeds finished in feedlot. According to Gonsalves, Monte, Villarroel, Damaceno and Cavalcante (2012), meat with shear force less than $8 \mathrm{kgf}$ $\mathrm{cm}^{-2}$ are considered soft; between 8 and 11 $\mathrm{kgf} \mathrm{cm}^{-2}$ acceptable and, above $11 \mathrm{kgf} \mathrm{cm}^{-2}$ hard.

Loss on thawing and cooking did not differ significantly $(P>0.05)$ between the production systems pasture $2.70 \pm 1.12 \%$ and $22.61 \pm 2.59 \%$, silvopastoral system 4.09 $\pm 0.31 \%$ and $24.92 \pm 3.20 \%$ and feedlot 3.44 $\pm 0.45 \%$ and $29.28 \pm 4.46 \%$, respectively. The water holding capacity is an important parameter to be evaluated, because in addition to affecting the appearance and behavior of meat during cooking it also gives the sensation of greater or lesser juiciness during chewing (Polli et al., 2020; Luiggi et al., 2020). Benaglia et al. (2016), evaluated Suffolk crossbred lambs and found average values of $9.73 \%$ for thawing losses in the longissimus dorsi muscle, which is higher than the overall average of the present study (3.41\%). The authors also verified the cooking losses of $23.43 \%$, which are similar to the values observed in this study. 


\section{Conclusion}

The productive potential of the feedlot system was evident due to the observed parameters, which were superior to the other evaluated production systems. The pasturebased production systems (pasture without shading and Silivopastoral) were similar to each other, demonstrating its potential in also providing good results on the qualitative and quantitative characteristics of carcass and meat of lambs.

\section{Acknowledgements}

The authors would like to thank the Coordenação de Aperfeiçoamento de Pessoal de Nível Superior (CAPES) for financial support of this study (finance code 001).

\section{References}

Alves, D. D., Araújo, L. M., Monteiro, H. C. F., Lonel, F. P., Silva, F. V., Simões, D. A.,... Brant, L. M. S. (2013). Características de carcaça, componentes não-carcaça e morfometria em ovinos submetidos a diferentes estratégias de suplementação. Semina: Ciências Agrárias, 34(6), 30933104. doi: 10.5433/1679-0359.2013v34 n6p3093

Alves, E. M., Pedreira, M. S., Moreira, B. S., Freire, L. D. R., Lima, T. R., \& Santos-Cruz, C. L. (2014). Carcass characteristics of sheep fed diets with slow-release urea replacing conventional urea. Acta Scientiarum Animal Sciences, 36(3), 303-310. doi: 10.4025/actascianimsci.v36i3.21379

Alves, L. G. C., Osório, J. C. S., Osório, M. T. M., Fernandes, A. R. M., Ribeiro, E. L. A., Cunha,
C. M.,... Fuzikawa, I. H. S. (2015). Avaliação da composição regional e tecidual da carcaça ovina. Pubvet, 9(1), 1-51.

Amaral, R. M., Macedo, F. A. F., Alcalde, C. R., Lino, D. A., Bánkuti, F. I., Macedo, F. G.,... Gualda, T. P. (2011). Desempenho produtivo e econômico de cordeiros confinados abatidos com três espessuras de gordura. Revista Brasileira de Saúde e Produção Animal, 12(1), 155-165.

Atti, N., \& Mahouachi, M. (2011). The effects of diet, slaughter weight and docking on growth, carcass composition and meat quality of fat-tailed Barbarine lambs. A review. Tropical Animal Health and Production, 43(7), 1371-1378. doi: 10.1007/s11250-011-9865-6

Azeredo, H. M. C., Brito, E. S., \& Garruti, D. S. (2012). Fundamentos de estabilidade de alimentos. In H. M. C. de Azeredo (Ed.), Alterações químicas em alimentos durante a estocagem (pp. 39-75). Brasília, DF: EMBRAPA.

Barros, M. C. C., Marques, J. A., Silva, R. R., Silva, F. F., Costa, L. T., Guimarães, G. S.,... Gusmão, J. J. N. (2015). Viabilidade econômica do uso da glicerina bruta em dietas para cordeiros terminados em confinamento. Semina: Ciências Agrárias, 36(1), 443-452. doi: 10.5433/ 1679-0359.2015v36n1p443

Benaglia, B. B., Morais, M. G., Oliveira, E. R., Comparin, M. A. S., Bonin, M. N., Feijó, G. L. D.,... Fernandes, H. J. (2016). Características quantitativas e qualitativas da carcaça e da carne de cordeiros alimentados com torta de girassol. Revista Brasileira de Saúde e Produção Animal, 17(2), 222-236. doi: 10.1590/S1519-99402016000200010 
Bertol, T. M. (2019). Estratégias nutricionais para melhoria da qualidade da carne suína. Brasília, DF: EMBRAPA.

Bertol, T. M., Oliveira, E. A., Coldebella, A., Kawski, V. L., Scandolera, A. J., \& Warpechowski, M. B. (2015). Meat quality and cut yield of pigs slaughtered over $100 \mathrm{~kg}$ live weight. Arquivo Brasileiro de Medicina Veterinária e Zootecnia, 67(4), 1166-1174. doi: 10.1590/1678-41628113

Cañeque, V., \& Sañudo, C. (2005). Estandarización de las metodologías para evaluar la calidad del producto (animal vivo, canal, carne y grasa) en los ruminantes. Madri: INIA.

Cartaxo, F. Q., Sousa, W. H., Cezar, M. F., Cunha, M. G. G., Menezes, L. M., Ramos, J. P. F.,... Viana, J. A. (2017). Performance and carcass traits of Santa Ines pure lambs and crosses with Dorper finished in feedlot. Revista Brasileira de Saúde e Produção Animal, 18(2), 388-401. doi: 10.1590/s1519-99402017000200017

Carvalho, S., Pires, C. C., Wommer, T. P., Pelegrin, A. C., Moro, A., Venturini, R., \& Brutti, D. (2012). Características da carcaça de cordeiros alimentados com dietas contendo diferentes resíduos agroindustriais. Revista Agrarian, 5(18), 409-416.

Castro, W. J. R., Zanine, A. M., Souza, A. L., Ferreira, D. J., Geron, L. J. V., Leão, A. G.,... Ferro, M. M. (2016). Inclusion of different levels of common-bean residue in sheep diets on nutrient intake and digestibility. Semina: Ciências Agrárias, Londrina, 37(1), 369-380. doi: 10.5433/1679-03 59.2016v37n1p369
Cézar, M. F., \& Sousa, W. H. (2007). Carcaças ovinas e caprinas: obtenção, avaliação e classificação. Uberaba, MG: Editora Agropecuária Tropical.

Colomer-Rocher, F., Morand-Fehr, P., \& Kirton, A. H. (1987). Standard methods and procedures for goat carcass evaluation, jointing and tissue separation. Livestock Production Science, 17(1), 149-159. doi: 10.1016/0301-6226(87)90060-1

Cruz, B. C. C., Santos, C. L., Azevedo, J. A. G., \& Silva, D. A. (2016). Avaliação e composição centesimal e as características físicoquímicas da carne de ovinos. Pubvet, 10(2), 147-162. doi: 10.22256/pubvet.v10 n2.147-162

Estremote, M., Melo, V. F. P., \& Pinheiro, R. S. B. (2015). Sistema silvipastoril na produção de ovinos. Periódico Eletrônico Fórum Ambiental da Alta Paulista, 11(2), 1-15. doi: 10.17271/1980082711220151100

Faria, P. B., Silva, J. N., Rodrigues, A. Q., Teixeira, P. D., Melo, L. Q., Costa, S. F., \& Pereira, A. A. (2011). Processamento da casca de mandioca na alimentação de ovinos: desempenho, características de carcaça, morfologia ruminal e eficiência econômica. Revista Brasileira de Zootecnia, 40(12), 2929-2937. doi: 10. 1590/S1516-35982011001200041

Ferreira, R. A., Estrada, L. H. C., Thiébaut, J. T. L., Granados, L. B. C., \& Souza, V. R., Jr. (2011). Avaliação do comportamento de ovinos Santa Inês em sistema silvipastoril no norte fluminense. Ciência e Agrotecnologia, 35(2), 399-403. doi: 10.1590/S1413-70542011000200023

Garcia, C. A., Cidrão, K., Spers, R. C., Colombo, D., \& Trevizan, B. A. (2016). Produção 
de cordeiros em regime de pasto, com suplementação mineral e proteica em cochos privativos. Revista Unimar Ciências, 25(1-2), 57-67.

Gois, G. C., Santos, E. M., Sousa, W. H., Ramos, J. P. F., Azevedo, P. S., Oliveira, J. S.,... Perazzo, A. F. (2017). Qualidade da carne de ovinos terminados em confinamento com dietas com silagens de diferentes cultivares de sorgo. Arquivo Brasileiro de Medicina Veterinária e Zootecnia, 69(6), 1653-1659. doi: 10.1590/1678-41629231

Gonsalves, H. R. O., Monte, A. L. S., Villarroel, A. B. S., Damaceno, M. N., \& Cavalcante, A. B. D. (2012). Qualidade da carne de caprinos e ovinos: uma revisão. Agropecuária Científica no Semi-Árido, 8(3), 11-17. doi: 10.30969/acsa.v8i3.161

Guerrero, A., Valero, M. V., Campo, M. M., \& Sañudo, C. (2013). Some factors that affect ruminant meat quality: from the farm to the fork. Review. Acta Scientiarum Animal Sciences, 35(4), 335-347. doi: 10. 4025/actascianimsci.v35i4.21756

Hamm, R. (1961). Biochemistry of meat hydratation. Advances in Food Research Cleveland, 10(2), 355-463. doi: 10.1016/ S0065-2628(08)60141-X

Hashimoto, J. H., Osório, J. C. S., Osório, M. T., Bonacina, M. S., Lehmen, R. I., \& Pedroso, C. E. S. (2012). Carcass quality, parts and tissue development of lambs finished in three systems. Revista Brasileira de Zootecnia, 41(2), 438-448. doi: 10.1590/ S1516-35982012000200029

Instituto Agronômico do Paraná (2011). Cartas climáticas do Paraná. Curitiba, PR: IAPAR.
Jucá, A. F., Faveri, J. C., Melo, G. M., Fo., Ribeiro, A. L., Fo., Azevedo, H. C., Muniz, E. N.,... Pinto, L. F. B. (2016). Effects of birth type and family on the variation of carcass and meat traits in Santa Ines sheep. Tropical Animal Health and Production, 48(2), 435443. doi: 10.1007/s11250-015-0971-8

Kirton, A. H. (1986). Animal industries workshop Lincoln College, technical handbook. Canterbury: Lincoln College.

Landim, A. V., Costa, H. H. A., Carvalho, F. C., Costa, A. C., Alencar, R. T., Silva, L. N. C.,... Lima, L. D. (2017). Desempenho produtivo e características de carcaça de cordeiros Rabo Largo puro e cruzados com Santa Inês. Arquivo Brasileiro de Medicina Veterinária e Zootecnia, 69(5), 1267-1274. doi: 10.1590/1678-4162-9210

Leão, A. G., Silva, A. G., Sobrinho, Moreno, G. M. B., Souza, H. B. A., Giampietro, A., Rossi, R. C., \& Perez, H. L. (2012). Características físicoquímicas e sensoriais da carne de cordeiros terminados com dietas contendo cana-de-açúcar ou silagem de milho e dois níveis de concentrado. Revista Brasileira de Zootecnia, 41(5), 1253-1262. doi: 10.1590/S1516-359820 12000500024

Leite, H. M. S., Batista, N. V., Lima, A. F., Silva, L. A., Oliveira, J. T. M. C. B., Firmino, S. S.,... Lima, P. O. (2020). Desempenho e comportamento ingestivo de cordeiros alimentados com dieta de alto grão. Research, Society and Development, 9(10), 2559108443-2559108443. doi: 10. 33448/rsd-v9i10.8443

Lima, L. D., Rêgo, F. C. A., Koetz, C., Jr., Ribeiro, E. L. A., Constantino, C., Belan, L.,... Zundt, M. (2013). Interferência da dieta de alto 
grão sobre as características da carcaça e carne de cordeiros Texel. Semina: Ciências Agrárias, 34(2), 4053-4064. doi: 10.54 33/1679-0359.2013v34n6Supl2p4053

Lima, M. C., Vargas, F. M., Jr., Martins, C. F., Pinto, G. S., Nubiato, K. E. Z., \& Fernandes, A. R. M. (2012). Características de carcaça de cordeiros nativos de Mato Grosso do Sul terminados em confinamento. Revista Agraria, 5(18), 384-392.

Lira, A. B., Gonzaga, S., Neto, Sousa, W. H., Ramos, J. P. F., Cartaxo, F. Q., Santos, E. M.,... Freitas, F. F. (2017). Desempenho e características de carcaça de dois biótipos de ovinos da raça Santa Inês terminados a pasto suplementados com blocos multinutricionais. Revista Brasileira de Saúde e Produção Animal, 18(2), 313-326. doi: 10.1590/s1519-99 402017000200010

Luiggi, F. G. G., Pacheco, P. D. G., Racanicci, A. M. C., Muynarsk, E. S. M., Fasanaro, R., \& Sartori, J. R. (2020). Uso de bixina na dieta de frangos de corte e seus efeitos no desempenho zootécnico e qualidade da carne. Archives of Veterinary Science, 25(1), 95-108. doi: 10.5380/avs. v25i1.67904

Mcmanus, C., Paim, T. P., Louvandini, $H_{\text {., }}$ Dallago, B. S. L., Dias, L. T., \& Teixeiras, R. A. (2013). Avaliação ultrassonográfica da qualidade de carcaça de ovinos Santa Inês. Ciência Animal Brasileira, 14(1), 8-16. doi: 10.5216/cab.v14i1.12336

Moreno, G. M. B., \& Boaventura, O., Neto. (2016). Avaliação e cortes da carcaça em ovinos e caprinos. Ciência Veterinária nos Trópicos, 19(2), 32-41.
Mott, G. O., \& Lucas, H. L. (1952). The design, conduct, and interpretation of grazing trials on cultivated and improved pastures. Proceedings of the International Grassland Congress, Pennsylvania, USA, 6.

Muller, L. (1987). Normas para avaliação de carcaças e concurso de carcaça de novilhos. Santa Maria, RS: Imprensa Universitária.

National Research Council (2007). Nutrients requirements of small ruminants. Washington, D.C.: National Academy Press.

Oliveira, J. P. F., Ferreira, M. A., Freitas, A. P. D., Urbano, A. S., \& Silva, A. E. M. (2017). Características de carcaça de ovinos Santa Inês alimentados com mazoferm substituindo o farelo de soja. Revista Ciência Agronômica, 48(4), 708. doi: 10.5935/1806-6690.20170082

Osório, J. C. S. (1998). Métodos para avaliação da produção de carne ovina: 'in vivo', na carcaça e na carne. Pelotas, RS: Universidade Federal de Pelotas.

Osório, J. C. S., \& Osório, M. T. M. (2005). Produção de carne ovina: técnicas de avaliação "in vivo" e na carcaça. Pelotas, RS: Universidade Federal de Pelotas.

Pellegrini, A. C. R. S., Pires, C. C., Mello, R. O., Venturini, R. S., Simões, R. R., Bernardes, G. M. C.,.. Mello, V. L. (2018). Carcass and body components of suckling lambs grazing ryegrass and supplemented with legume or concentrate. Arquivo Brasileiro de Medicina Veterinária e Zootecnia, 70(3), 975-982. doi: 10.1590/1678-4162-9787 
Pilecco, V. M., Carvalho, S., Pellegrini, L. G., Mello, R. O., Pacheco, O. S., Pellegrini, A. C. R. S.,... Mello, V. L. (2018). Carcaça e componentes não carcaça de cordeiros terminados em confinamento com caroço de algodão na dieta. Arquivo Brasileiro de Medicina Veterinária e Zootecnia, 70(6), 1935-1942. doi: 10.1590/1678-41629433

Polli, V. A., Costa, P. T., Garcia, J. A. B., Restle, J., Dutra, M. M. M., \& Vaz, R. Z. (2020). Estresse térmico e qualidade da carne ovina-uma revisão. Research, Society and Development, 9(9), 595997578595997578. doi: 10.33448/rsd-v9i9.7578

Porto, P. P., Martins, J. C., Pedrozo, D. J., Valério, M. A., \& Ciavarelli., L. A., Jr. (2016). Comportamento do híbrido Eucalyptus urograndis em sistema silvipastoril (SSP) com ovinos. Synergismus Scyentifica UTFPR, 11(1), 55-57.

Queiroz, L. O., Santos, G. R. A., Macêdo, F. A. F., Mora, N. H. A. P., Torres, M. G., Santana, T. E. Z., \& Macêdo, F. G. (2015). Características quantitativas da carcaça de cordeiros Santa Inês, abatidos com diferentes espessuras de gordura subcutânea. Revista Brasileira de Saúde e Produção Animal, 16(3), 712-722. doi: 10.1590/ S1519-99402015000300021

Rodrigues, R. C. (2009). Avaliação químicobromatológica de alimentos produzidos em terras baixas para nutrição animal. Pelotas, RS: EMBRAPA.

Russel, A. J. F., Doney, J. M., \& Gunn, R. G. (1969). Subjective assessment of body fat in live sheep. Journal Agricultural Science, 72(3), 451-454. doi: 10.1017/ S0021859600024874
Santos, N. L., Azenha, M. V., Souza, F. H. M., Reis, R. A., \& Ruggieri, A. C. (2011). Fatores ambientais e de manejo na qualidade de pastos tropicais. Enciclopédia Biosfera, 7(13), 531-549.

Sañudo, C., \& Sierra, I. (1986). Calidad de la canal en la especie ovina. Ovino, 1(1), 127-153.

SAS Institute. (2001). SAS/STAT User's guide. Version 9.1. Led, Cary.

Silva, A. G., Sobrinho. (2001). Criação de ovinos. Jaboticabal, SP: FUNEP.

Silva, A. G., Sobrinho, \& Osório, J. C. S. (2008). Aspectos quantitativos da produção de carne ovina. In Silva, A. G., Sobrinho, Sañudo, C., Osório, J. C. S., Arribas, M. M. C. \& Osório, M. T. M. Produção de carne ovina (pp. 1-68). Jaboticabal, SP: FUNEP.

Silva, A. G., Sobrinho, Purchas, R. W., Kadim, I. T., \& Yamanoto, S. M. (2005). Musculosidade e composição da perna de ovinos de diferentes genótipos e idades de abate. Pesquisa Agropecuária Brasileira, 4O(11), 1129-1134. doi: 10.1590/S0100204X2005001100011

Silva, D. L. S., Braga, A. P., Pontes, F. S. T., Lima, D. M., Jr., Costa, W. P., Chaves, V. V.,.. Braga, Z. C. A. C. (2015). Morfometria corporal e de carcaça de ovinos alimentados com torta de girassol. Acta Veterinária Brasilica, 9(4), 306-315. doi: 10.21708/ avb.2015.9.4.5376

Silva, N. V., Costa, R. G., Medeiros, G. R., Gonzaga, S., Neto, Cézar, M. F., \& Cavalcanti, M. C. A. (2016). Medidas in vivo e da carcaça e constituintes não carcaça de ovinos alimentados com diferentes níveis do subproduto agroindustrial da 
goiaba. Revista Brasileira de Saúde e Produção Animal, 17(1), 101-115. doi: 10.1590/S1519-99402016000100010

Vargas, F. M., Jr., Martins, C. F., Feijó, G. L. D., Teixeira, A., Leonardo, A. P., Ricardo, H. A.,... Reis, F. A. (2019). Evaluation of genotype on fatty acid profile and sensory of meat of indigenous Pantaneiro sheep and Texel or Santa Inês crossbred finished on feedlot.
Small Ruminant Research, 173(1), 17-22. doi: 10. 1016/j.smallrumres.2019.02.003

Wilm, H. G., Costello, D. F. \& Klipple, G. E. (1944). Estimating forage yield by the 11 doublesampling methods. Journal of American Society of Agronomy, 36(12), 194-203. doi: 10.2134/agronj1944.000219620036 $00030003 x$ 
